\title{
Physical Exercise in Major Depression: Reducing the Mortality Gap While Improving Clinical Outcomes
}

\begin{abstract}
Martino Belvederi Murri 1,2,3*, Panteleimon Ekkekakis ${ }^{4}$, Marco Magagnoli ${ }^{1}$, Domenico Zampogna ${ }^{1}$, Simone Cattedra ${ }^{1}$, Laura Capobianco ${ }^{1}$, Gianluca Serafini ${ }^{1,2}$, Pietro Calcagno ${ }^{1}$, Stamatula Zanetidou ${ }^{5}$ and Mario Amore ${ }^{1,2}$

${ }^{1}$ Section of Psychiatry, Department of Neuroscience, Ophthalmology, Genetics and Infant-Maternal Science, University of Genoa, Genoa, Italy, ${ }^{2}$ IRCCS Ospedale Policlinico San Martino, Genova, Italy, ${ }^{3}$ Department of Psychological Medicine, King's College London, London, United Kingdom, ${ }^{4}$ Department of Kinesiology, lowa State University, Ames, IA, United States, ${ }^{5}$ Department of Mental Health, Consultation Liaison Psychiatry Service, Bologna, Italy
\end{abstract}

Major depression shortens life while the effectiveness of frontline treatments remains modest. Exercise has been shown to be effective both in reducing mortality and in treating symptoms of major depression, but it is still underutilized in clinical practice, possibly due to prevalent misperceptions. For instance, a common misperception is that exercise is beneficial for depression mostly because of its positive effects on the body ("from the neck down"), whereas its effectiveness in treating core features of depression ("from the neck up") is underappreciated. Other long-held misperceptions are that patients suffering from depression will not engage in exercise even if physicians prescribe it, and that only vigorous exercise is effective. Lastly, a false assumption is that exercise may be more harmful than beneficial in old age, and therefore should only be recommended to younger patients. This narrative review summarizes relevant literature to address the aforementioned misperceptions and to provide practical recommendations for prescribing exercise to individuals with major depression.

Keywords: depression, mortality, exercise, physical activity, efficacy, cardiovascular disease

\section{INTRODUCTION}

Depression exerts an enormous impact on different domains of individual functioning, as well as physical health $(1,2)$. Physical exercise is increasingly recognized as an effective intervention to improve these outcomes.

Patients with major depression seldom receive adequate treatment. When they do, there is a high likelihood they remain depressed or relapse after first-line treatment $(3,4)$. Whereas, a substantial proportion of patients go on to receive intensive pharmacological care $(5,6)$.

Besides mental health outcomes, recent studies cast great concern on the physical health of depressed individuals. Depression is, in fact, accompanied by behavioral and biological features that are deleterious for physical health, particularly in the cardiovascular system (7). Moreover, when depression arises as a consequence of pre-existing physical problems, it may amplify disability, anticipate recurrences, and increase disease-related mortality $(8,9)$. Recently it was estimated that individuals with major depression die, on average, about 10 years earlier than those who are not depressed, even when excluding deaths by suicide (10-12). 
There is wide agreement that current research and clinical efforts to address these issues are arguably not proportional to their gravity. There is an urgent need to develop and implement novel treatments that are effective to treat symptoms of depression and, at the same time, are beneficial for physical health (13). One such intervention is physical exercise, which is increasingly recognized as both an antidepressant agent (14) and a potent tool to delay mortality (15). The aim of this perspective article is to provide a concise update on the effectiveness of exercise for depression and cardiovascular mortality reduction. A specific section is dedicated to treatment of elderly patients, in consideration of their increasing demographic relevance (2). English-language reviews and meta-analyses published in the last 10 years were considered, identified with the following search string in the Pubmed database: (exercis*[ti] OR "physical activity"[ti]) AND depress*[ti] AND (review*[pt] OR review*[tiab]).

\section{DEPRESSION IS ASSOCIATED WITH A SHORTER LIFESPAN}

Even if a direct causal role is still debated (16), depression could increase mortality through several mechanisms (10). First, it negatively impacts lifestyle choices. Individuals with depression tend to be sedentary $(17,18)$ and less physically fit than their non-depressed counterparts (19). Moreover, they exhibit higher rates of cigarette smoking (20-22), consume more alcohol (23), adopt low-quality dietary regimens (24), and become overweight $(25,26)$. Of note, some of these associations seem underlined by bi-directional causal links.

Second, depression is accompanied by dysregulation of several homeostatic systems (27). Depressed individuals commonly display dysregulation of the hypothalamic-pituitaryadrenocortical (HPA) axis (28-30), immune (31, 32), and autonomic nervous system (33), as well as metabolic imbalances (34).

Third, depression can raise mortality risk by increasing the incidence of physical illnesses or worsening the outcomes of existing ones. For instance, the presence of clinically significant depression has been found to increase the incidence and mortality of cardiovascular diseases $(35,36)$, as well as the mortality due to diabetes (37) and stroke (38). This phenomenon could stem, among other reasons, from placing additional stress on disorder-specific pathophysiologic mechanisms, but may also reflect poor adherence to medications or problematic health behaviors (39-41). In this regard, Table 1 reports an overview of the relationship between depression, cardiovascular risk factors, and mortality.

\section{EXERCISE IS EFFECTIVE FOR THE PHYSICAL HEALTH OF DEPRESSED PATIENTS}

Physical activity and exercise have a wide range of beneficial effects (72) that involve both "body" and "mind." Bearing in mind this is an artifactual and anachronistic convention, here we provide an overview of exercise effects on the body "from the neck down" that could be relevant to individuals with depression.

Table 1 reports recent literature addressing this issue.

Together with dietary caloric restriction, exercise is the main component of interventions that are effective at reducing and managing weight (73-75). The positive effect of exercise is likely mediated by enhanced regulation of appetite hormones (76) and by increased metabolic rate $(47,77,78)$. Moreover, exercise improves sleep quality and duration (79).

Exercise also causes beneficial adaptations in homeostatic systems involved in the response to stress, including the HPA axis (80-82). Moreover, it dampens inflammatory processes while delaying the aging of the immune system (51-53). Exercise also improves the autonomic visceral control by restoring sympathovagal balance $(57,83,84)$ Finally, it improves cardiorespiratory fitness both in healthy individuals (47) and individuals with depression (85).

While the formal acknowledgment of the salutary effects of exercise in the medical sciences has been a lengthy process, regular exercise is now recognized as an important lifestyle behavior that can ameliorate the negative impact of chronic diseases (86). Overall, it is estimated that exercise can reduce mortality to a similar extent as medications in individuals with coronary heart disease, stroke, heart failure, and diabetes (15). It would be urgent to verify if such findings can be translated to depressed subjects.

Among the many salutary effects of exercise, arguably the least researched-and probably the most controversial-are its effects on other lifestyle and health behaviors. Both the number of randomized controlled trials and the methodological quality of the trials in this area are rising. While concepts and methods continue to evolve, some early results related to smoking cessation and reducing problem drinking among individuals with mental health disorders show promise (87-89). However, at this stage, systematic reviews of the evidence on the effectiveness of exercise in promoting abstinence from smoking (60) or alcohol (58) indicate no beneficial effect. On the other hand, the effect of exercise on reducing the use of illegal substances is significant (90). In addition, whether a structured exercise intervention can reduce sedentary behavior or encourage engagement in subsequent physical activity remains hotly debated (64).

\section{EXERCISE IS EFFECTIVE AGAINST SYMPTOMS OF MAJOR DEPRESSION}

Physical exercise has been shown to be an effective treatment for major depression in adults $(14,91)$ in several randomized controlled trials comparing it to a wide range of other treatments, including usual care, psychological interventions, and antidepressant medications (14,92). Although there have been contrarian meta-analytic findings [e.g., (93)], closer inspection of methodological details reveals a pattern of debatable choices (91).

Exercise interventions consisting of three sessions per week for 12-24 weeks typically result in a medium to large reduction in the severity of depression, measured by symptom 
TABLE 1 | Literature examining the relationship between depression, cardiovascular risk factors, cardiovascular mortality, and physical exercise in adults.

\begin{tabular}{lll}
\hline $\begin{array}{l}\text { Cardiovascular risk } \\
\text { factor }\end{array}$ & Association between depression and risk factor & $\begin{array}{l}\text { Effect of exercise on risk factor among non-depressed } \\
\text { populations }\end{array}$
\end{tabular}

\section{factor}

Obesity-overweight

Type 2 Diabetes

Unbalanced diet

Blood metabolic parameters Depression was associated with a higher prevalence of Metabolic Syndrome (OR: 1.54, 95\% Cl 1.21-1.97), hyperglycemia (OR: 1.33, 95\% Cl: 1.03-1.73), hypertriglyceridemia (OR: 1.17, 95\% C 1.04-1.30). Eighteen studies, all cross-sectional (34). Depression was associated with lower serum LDL levels (mean difference: 3.15 mg/dL, 95\%Cl: 6.05-0.24). Eighteen cohort studies (46)

Hypertension

Inflammation

Alcohol use

Cigarette smoking

Adherence to medications

Physical inactivity/sedentary behavior

Depression had a $37 \%$ increased risk of becoming obese (RR: 1.37, 95\%Cl: 1.17-1.48); risk was highest for young and middle aged women. Nineteen prospective studies $(26,42)$

Depression was associated with an increased risk of having T2DM (RR: 1.49; 95\%Cl: 1.29-1.72). Ten studies, only one prospective (44)

Two out of three studies supported an association between depression and unbalanced diet. Three studies, all cross sectional (24)

Depression was associated with an increased risk of incident hypertension (RR: 1.42, 95\% Cl: 1.09-1.86). Nine prospective studies (48)

Depression was associated with abnormal levels of peripheral cytokines and chemokines compared to HCs. IL-6, TNF-a, IL-10, sIL-2R, CCL-2, IL-13, IL-18, IL-12, and sTNFR2 were significantly elevated, IFN-gamma was slightly reduced. Eighty-two case-control studies (50)

Untreated depression was associated with reduced Heart Rate Variability (g: $-0.349,95 \% \mathrm{Cl}:-0.51$ to -0.19$)$. Twenty-nine case-control studies (54)

Depression was associated with increased risk of Alcohol Use Disorders (aOR: 2.09, 95\%Cl: 1.29-3.38). Seven studies, two of which prospective (23)

Among adolescents, depression increased the risk of beginning smoking (RR: 1.41, 95\% Cl: 1.21-1.63). Twelve prospective studies (20). Depressed smokers had lower odds of short-term (OR: 0.83, 95\% $\mathrm{Cl}$ : 0.72-0.95) and long-term abstinence (OR: 0.81, 95\% Cl: 0.67-0.97). Forty-two clinical trials on smoking cessation (59)

Depression was associated with an increased likelihood of non-adherence to medications (OR: 1.76, 95\% Cl: 1.33-2.57).

Thirty-one U.S. based cross-sectional studies on chronic diseases (61)

Depression was associated with less time spent for total Physical Activity (SMD: $-0.25,95 \% \mathrm{Cl}:-0.03-0.15)$, higher levels of Sedentary Behavior (SMD: 0.09, 95\%Cl: 0.01-0.18) and lower likelihood to meet physical activity levels recommended by guidelines (OR: $-1.50,95 \% \mathrm{Cl}:-1.10$ to -2.10$)$. Twenty-four cross sectional studies (17). A recent large study confirmed the association between mental health and physical activity levels (62)

\section{Cardiovascular mortality Association between depression and mortality}

Coronary heart disease

Depression was associated with an increased risk of myocardial infarction-related death (HR: 1.31, 95\%Cl: 1.09-1.57) and coronary death (HR: 1.36; 95\%Cl: 1.14-1.63). Nineteen prospective studies (66). Quality of evidences appraised as "highly suggestive" (16)

Arrhythmias related mortality Depression was associated with an increased risk of Sudden Cardiac Death (HR: 1.62; 95\%Cl: 1.37-1.92), ventricular arrhythmias (HR: $1.47 ; 95 \% \mathrm{Cl}: 1.23-1.76)$ recurrence of Atrial Fibrillation (HR: 1.88; 95\%Cl: 1.54-2.30). Seventeen studies, of which 15 prospective (36)

populations

Exercise was effective to reduce body weight (although less effective than hypocaloric diet) and visceral adipose tissue (more effective than hypocaloric diet). 117 trials (43)

Exercise improved $\mathrm{Hb} 1 \mathrm{AC}$ levels and insulin resistance. 27 trials (45)

na

Exercise lowered fasting insulin, HOMA-IR, and Hb1AC levels. TG and APOA1 levels, increased HDL levels; trend-level effects for reductions of LDL and fasting glucose. $160 \mathrm{RCTs}$ (47)

Exercise reduced blood pressure. The magnitude of the effect changed according to exercise type and was greater for hypertensive subjects. 93 RCTs (49)

Exercise reduced IL6 and CRP levels in T2DM. Fourteen RCTs (51). Similar results in CAD. Twenty-six trials (52). Possible effect enhancing immune competence and delaying the aging of the immune system (53)

Exercise increased HRV in 9 out of 15 trials on T2DM (55). Exercise improved HRV in CAD. Sixteen RCTs (56). Exercise improved HRV in HF. 19 trials (57)

Exercise did not reduce daily alcohol consumption or AUDIT total scores. 21 trials (58)

No effect of exercise on smoking cessation. 19 RCTs (60)

na

Exercise interventions yielded uncertain and/or small effects increasing subsequent physical activity (63-65)

\section{Effect of exercise on mortality among non-depressed populations}

Exercise reduced mortality in coronary heart disease (OR: 0.89, 95\%Credible Interval: 0.76-1.04) with no difference in magnitude from ACEi, beta-blockers, ARBs and diuretics. Thirty-four RCTs

(15). Exercise-based Cardiac Rehabilitation reduced cardiovascular, but not overall mortality (RR: $0.74,95 \% \mathrm{Cl}$ 0.64-0.86). 27 RCTs (67)

No clear effect of exercise on mortality in Atrial Fibrillation (RR: 1.00; 95\% Cl: 0.06-15.78). 6 RCTs (68) 
TABLE 1 | Continued

\begin{tabular}{|c|c|c|}
\hline Cardiovascular mortality & Association between depression and risk factor & $\begin{array}{l}\text { Effect of exercise on risk factor among non-depressed } \\
\text { populations }\end{array}$ \\
\hline Mortality in Heart Failure & $\begin{array}{l}\text { Depression was associated with an increased risk of all-cause } \\
\text { mortality (HR: } 1.20 ; 95 \% \mathrm{Cl} \text { : 1.10-1.31). Increased risk was driven } \\
\text { by studies on participants older than } 65.14 \text { prospective studies } \\
\text { (35). Quality of evidences was appraised as "highly suggestive" } \\
\text { (16) }\end{array}$ & $\begin{array}{l}\text { Exercise reduced mortality in heart failure (OR: } 0.79 ; 95 \% \text { Credible } \\
\text { Interval: } 0.59-1.00) \text { to a greater extent than ACEi, beta-blockers, } \\
\text { ARBs, but less than diuretics. } 18 \text { RCTs (15) }\end{array}$ \\
\hline $\begin{array}{l}\text { Mortality after Cardiac } \\
\text { Surgery }\end{array}$ & $\begin{array}{l}\text { Perioperative depression was associated with an increased risk of } \\
\text { early (RR: } 1.44 ; 95 \% \mathrm{Cl}: 1.01-2.05 \text { ) and late postoperative } \\
\text { mortality (RR: } 1.44 ; 95 \% \mathrm{Cl}: 1.24-1.67) \text {. Sixteen prospective } \\
\text { studies (69) }\end{array}$ & $\begin{array}{l}\text { Insufficient evidence to establish a significant effect of exercise or } \\
\text { mortality after heart valve surgery. } 2 \text { RCTs (70) }\end{array}$ \\
\hline Overall mortality & $\begin{array}{l}\text { Depression was associated with an increased risk of mortality } \\
\text { relative to non-depressed participants (RR: } 1.52,95 \% \mathrm{Cl} \text { : } \\
\text { 1.45-1.59). Excess mortality risk was of similar magnitude in } \\
\text { patients from the community vs. those with specific diseases. Two } \\
\text { hundred and ninety-three prospective studies (10). Quality of } \\
\text { evidence was however appraised as inadequate to support a } \\
\text { direct causal association }(16,71)\end{array}$ & $\begin{array}{l}\text { The network meta-analysis estimated that exercise can reduce } \\
\text { mortality to a similar extent to medications among individuals with } \\
\text { coronary heart disease, stroke, heart failure, and diabetes. } 305 \\
\text { RCTs (15). }\end{array}$ \\
\hline
\end{tabular}

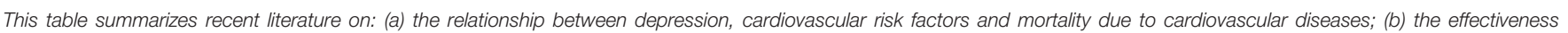

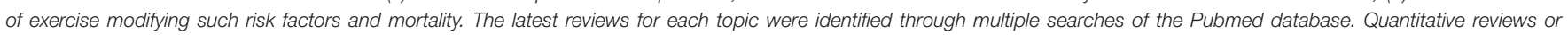
meta-reviews were preferred over qualitative or narrative ones. The number and type of primary studies is specified (cross-sectional vs. longitudinal; RCTs vs. controlled trials).

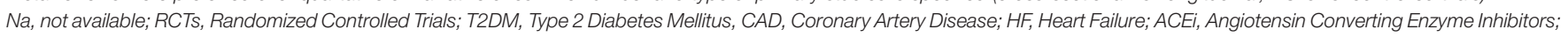
ARBs, Angiotensin II Receptor Blockers; OR, Odds Ratio; RR, Relative Risk; HR, Hazard Ratio; SMD, Standardized Mean Difference; Cl, Confidence Intervals.

rating scales (91). Moreover, exercise interventions have been found to result in $22 \%$ higher likelihood of remission from depression than treatment as usual (93), the latter in turn being associated with the remission of about a third of patients $(3,4)$. Generally, exercise is well-tolerated and leads to about $18 \%$ of dropout rates (94). Based on the available data, the efficacy of exercise seems greater if it is aerobic, delivered in groups, and supervised by an instructor (95). Although there are relatively few head-to-head comparisons and duration of treatment may be different, the efficacy of exercise may be comparable in terms of magnitude to that of psychotherapies $(3,94-97)$ or antidepressant medications (98).

Some authors claim the psychological effects of exercise largely depend on "placebo," or "non-specific" psychosocial effects, such as attention by staff $(99,100)$. Consistently, exercise is still listed among "alternative and complementary" therapies in some guidelines [e.g., (101)]. Skepticism has been fueled, among other reasons, by difficulties to demonstrate a clear dose-response relationship, such as would be expected in drug trials. Recent studies, however, have started to detect significant associations between the intensity and length of exercise interventions, and their antidepressant efficacy (102, 103); of note, such relationship is likely to follow non-linear patterns (104). Another long-held belief among clinicians is that exercise does only ameliorate non-specific somatic symptoms, such as sleep and appetite changes. Whereas, extant results suggest that exercise indeed reduces core symptoms of depression, such as depressed mood, anhedonia, and suicidal ideation (105, 106). On the other hand, studies examining the effects of exercise interventions on cognitive function among individuals with depression [e.g., (107)] at present do not indicate substantial benefits (108-110).
Exercise may be effective improving several biomarkers that have been implicated in depression (e.g., impaired neuroplasticity, autonomic, and immune imbalances). However, at present, evidence derived from non-depressed individuals still needs to be replicated among clinical populations (111). Nevertheless, recent trials have begun to show efficacy in treating patients with severe mood disorders (112-114) and individuals with treatment-resistant depression, either alone or as an addon to medications $(115,116)$. Lastly, exercise can be effective for individuals who may present concerns about drug treatment, such as women with pregnancy or post-partum depression (117) and adolescents $(118,119)$.

At present, research is still needed to establish the efficacy of exercise in the long-term course of major depression. Some analyses suggest that the antidepressant effects may diminish beyond the duration of the exercise intervention (92). However, individuals who regularly engage in moderate physical activity maintain reduced risk of incurring depressive episodes (120, 121).

\section{EFFECTIVENESS OF EXERCISE IN LATE LIFE DEPRESSION}

The clinical features and pathophysiology of late-life depression are largely distinct from that encountered among younger adults (122-124). Specifically, depression in late life is associated with a higher prevalence of physical illnesses, greater prevalence of cognitive impairments and inadequate response to antidepressant drugs (125-128). Despite these differences, late-life depression seems to respond to exercise as well as adult depression (129-131). Moreover, among studies appraised in recent meta-analyses, participants receiving exercise 
did not report any significant side effects. More recently, the SEEDS study showed that exercise was an effective add-on to antidepressant drugs for mild to moderate depression (132). Interestingly, adding exercise to antidepressant drugs primarily affected core symptoms of depression rather than somatic symptoms (133). Moreover, individuals receiving aerobic exercise plus antidepressants displayed greater improvements in cognition and autonomic balance compared to those only receiving antidepressants $(134,135)$. The intervention was well-received by patients and physicians alike (136).

Despite these promising results, the available evidence remains insufficient to conclude whether exercise can improve cognition in patients with late-life depression $(108,109)$. At present, studies suggest that exercise may not improve cognition among non-impaired, non-depressed individuals (137), but it may, to some extent, improve cognitive performance among individuals diagnosed with cognitive impairment (irrespective of depression), dementia, or physical diseases (138-141).

\section{HOW SHOULD EXERCISE BE PRESCRIBED TO INDIVIDUALS WITH DEPRESSION?}

Depression is usually treated by primary care physicians, psychiatrists, and psychologists. Exercise interventions can be delivered by professionals with a variety of disciplinary backgrounds, including group exercise leaders, personal trainers, clinical exercise physiologists, wellness specialists, and physical therapists. Given the challenging cognitive and affective features of depression, it is recommended that exercise for individuals with depression should be delivered by professionals with specific experience in mental health care (142). In other words, a well-integrated, collaborative approach is essential.

A collaborative approach begins with physicians willing to introduce the idea of exercise as a possible treatment options to individuals expressing depression complaints. However, proposals to introduce exercise to the armamentarium of interventions for the treatment of depression are often met with skepticism by physicians due to various perceived barriers $(143,144)$. These barriers may stem, at least in part, from high-profile reviews and treatment recommendations that downplay the relevant evidence. A recent review, for example, characterized any benefits of exercise, even against non-active control interventions, as merely "modest," alleged that "highquality clinical studies investigating the effect of exercise for treating depression among older patients are lacking," and raised doubt about whether older individuals with depression would be "willing to participate actively in an exercise program" (145). A counterpoint is that, to a large extent, such statements reflect a limited or outdated assessment of the evidence $(146,147)$. While the evidence base continues to evolve, there are already several randomized controlled trials with positive results that satisfy the standard criteria for high methodological quality (91). Furthermore, provided that proper therapeutic alliances are established within a stepped-care collaborative framework
(136), many individuals with subthreshold, mild, and moderate depressive symptoms will opt for exercise and will demonstrate satisfactory adherence.

Several groups have published recommendations for developing exercise prescriptions for individuals with depression, based on both empirical evidence and clinical experience (148152). While we endorse these recommendations, we should note that the optimal exercise prescription for the treatment of depression remains unknown, insofar as the relation between the "dose" of exercise (i.e., intensity, frequency, session duration) and the therapeutic response remains understudied. Therefore, any prescription recommendations at the present stage are essentially derived from general exercise prescription guidelines, which were developed primarily for the improvement and maintenance of physical fitness and cardiometabolic health (153). Therefore, we wish to highlight an emerging trend in exercise prescription, which may be especially relevant to the treatment of depression, namely affect-based exercise prescription (154). This method expands the traditional focus of exercise prescriptions from the dual goal of maximizing fitness gains while minimizing risk to a model that also aims to ensure that participants consistently derive pleasant affective experiences. The inclusion of pleasure as a central consideration is intended to enhance what is often the Achilles' heel of lifestyle or behavior-change interventions, namely adherence. In a typical affect-based prescription, the exercise participant is shown a simple rating scale (e.g., one ranging from +5 : "I feel very good" to -5 : "I feel very bad") and is instructed to self-regulate his or her exercise intensity and duration to maintain a rating of +3 or higher.

Individuals with depression can experience exercise as pleasant and affect-enhancing (155-157). Among non-depressed adults, affective responses to a bout of exercise have been found in correlational studies to be associated with the amount of physical activity individuals choose to do (158), while experimental manipulations resulting in improved affective responses have been shown to increase the amount of physical activity performed over a subsequent period of 6 months (159). Early evidence among individuals with depression indicates that affective responses to a bout of exercise may predict treatment response $(160,161)$. While randomized controlled trials investigating the efficacy, effectiveness, and cost-effectiveness of affect-based exercise prescriptions for the treatment of depression are not yet available, this method seems to hold promise for clinical application due to its simplicity, making it appealing to physicians who lack specialized training in exercise and to healthcare organizations concerned about implementation costs.

\section{CONCLUSIONS}

The premature mortality of individuals with depression is an alarming public health concern, which is exacerbated by the present inability to offer satisfactory treatments. Physical exercise represents an underutilized intervention that may uniquely address both concerns at the same time. 
First, exercise offers numerous physical benefits, which can counteract several mechanisms postulated to increase mortality risk in depression. Second, if prescribed and delivered correctly, exercise can be as effective as other first-line treatments, while being mostly free of adverse side-effects.

While there is a need of pragmatic trials to evaluate the long-term effects of exercise and its cost-effectiveness, clinicians in the mental health sector should acknowledge this ancient, yet new treatment option and should start to use it to the benefit of patients.

\section{REFERENCES}

1. Kessler RC. The costs of depression. Psychiatr Clin North Am. (2012) 35:114. doi: 10.1016/j.psc.2011.11.005

2. McCall WV, Kintziger KW. Late life depression: a global problem with few resources. Psychiatr Clin North Am. (2013) 36:475-81. doi: 10.1016/j.psc.2013.07.001

3. Cuijpers P, Karyotaki E, Weitz E, Andersson G, Hollon SD, Van Straten A. The effects of psychotherapies for major depression in adults on remission, recovery and improvement: a meta-analysis. J Affect Disord. (2014) 159:11826. doi: 10.1016/j.jad.2014.02.026

4. Kolovos S, van Tulder MW, Cuijpers P, Prigent A, Chevreul K, Riper H, et al. The effect of treatment as usual on major depressive disorder: a metaanalysis. J Affect Disord. (2017) 210:72-81. doi: 10.1016/j.jad.2016.12.013

5. Ijaz S, Davies P, Williams CJ, Kessler D, Lewis G, Wiles N. Psychological therapies for treatment-resistant depression in adults. Cochrane Database Syst Rev. (2018) 2018:CD010558. doi: 10.1002/14651858.CD010558.pub2

6. Shen MD, Piven J. Brain and behavior development in autism from birth through infancy. Dialogues Clin Neurosci. (2017) 19:325-33. doi: 10.1007/978-3-642-40308-8_2

7. Goldstein BI, Carnethon MR, Matthews KA, McIntyre RS, Miller GE, Raghuveer G, et al. Major depressive disorder and bipolar disorder predispose youth to accelerated atherosclerosis and early cardiovascular disease: a scientific statement from the american heart association. Circulation (2015) 132:965-86. doi: 10.1161/CIR.0000000000000229

8. Gleason OC, Pierce AM, Walker AE, Warnock JK. The two-way relationship between medical illness and late-life depression. Psychiatr Clin North Am. (2013) 36:533-44. doi: 10.1016/j.psc.2013.08.003

9. Shaffer JA, Edmondson D, Chaplin WF, Schwartz JE, Shimbo D, Burg MM, et al. Directionality of the relationship between depressive symptom dimensions and c-reactive protein in patients with acute coronary syndromes. Psychosom Med. (2011) 73:370-7. doi: 10.1097/PSY.0b013e31821deafd

10. Cuijpers P, Vogelzangs N, Twisk J, Kleiboer A, Li J, Penninx BW. Comprehensive meta-analysis of excess mortality in depression in the general community versus patients with specific illnesses. Am J Psychiatry (2014) 171:453-62. doi: 10.1176/appi.ajp.2013.13030325

11. Laursen TM, Musliner KL, Benros ME, Vestergaard M, Munk-Olsen T. Mortality and life expectancy in persons with severe unipolar depression. $J$ Affect Disord. (2016) 193:203-7. doi: 10.1016/j.jad.2015.12.067

12. Walker ER, McGee RE, Druss BG, Reisinger E, McGee RE, Druss BG. Mortality in mental disorders and global disease burden implications. a systematic review and meta- analysis JAMA Psychiatry (2015) 72:334-41. doi: 10.1001/jamapsychiatry.2014.2502.Mortality

13. Sampogna G, Fiorillo A, Luciano M, Del Vecchio V, Steardo L, Pocai B, et al. A randomized controlled trial on the efficacy of a psychosocial behavioral intervention to improve the lifestyle of patients with severe mental disorders: study protocol. Front Psychiatry (2018) 9:235. doi: 10.3389/fpsyt.2018. 00235

14. Schuch FB, Vancampfort D, Richards J, Rosenbaum S, Ward PB, Stubbs B. Exercise as a treatment for depression: a meta-analysis

\section{AUTHOR CONTRIBUTIONS}

MB and PE conceived and drafted the work. MM, DZ, SC, PC, LC, GS, SZ, and MA contributed to revising it critically and approving the content.

\section{FUNDING}

The study has been funded by a grant of the Italian Ministry of Education, Universities and Research within the framework of the Progetti di Rilevante Interesse Nazionale (PRIN) - year 2015. adjusting for publication bias. J Psychiatr Res. (2016) 77:42-51. doi: 10.1016/j.jpsychires.2016.02.023

15. Naci H, Ioannidis JPA. Comparative effectiveness of exercise and drug interventions on mortality outcomes: metaepidemiological study. Br J Sports Med. (2015) 49:1414-22. doi: 10.1136/bjsports2015f5577rep

16. Machado MO, Veronese N, Sanches M, Stubbs B, Koyanagi A, Thompson $\mathrm{T}$, et al. The association of depression and all-cause and cause-specific mortality: an umbrella review of systematic reviews and meta-analyses. BMC Med. (2018) 16:1-13. doi: 10.1186/s12916-018-1101-z

17. Schuch F, Vancampfort D, Firth J, Rosenbaum S, Ward P, Reichert T, et al. Physical activity and sedentary behavior in people with major depressive disorder: a systematic review and meta-analysis. J Affect Disord. (2017) 210:139-50. doi: 10.1016/j.jad.2016.10.050

18. Vancampfort D, Firth J, Schuch FB, Rosenbaum S, Mugisha J, Hallgren $\mathrm{M}$, et al. Sedentary behavior and physical activity levels in people with schizophrenia, bipolar disorder and major depressive disorder: a global systematic review and meta-analysis. World Psychiatry (2017) 16:308-15. doi: 10.1002/wps.20458

19. Papasavvas T, Bonow RO, Alhashemi M, Micklewright D. Depression symptom severity and cardiorespiratory fitness in healthy and depressed adults: a systematic review and meta-analysis. Sport. Med. (2016) 46:219-30. doi: 10.1007/s40279-015-0409-5

20. Chaiton MO, Cohen JE, O'Loughlin J, Rehm J. A systematic review of longitudinal studies on the association between depression and smoking in adolescents. BMC Public Health (2009) 9:1-11. doi: 10.1186/1471-2458-9-356

21. Lê Cook B, Wayne GF, Kafali EN, Liu Z, Shu C, Flores M. Trends in smoking among adults with mental illness and association between mental health treatment and smoking cessation. JAMA J Am Med Assoc. (2014) 311:172-82. doi: 10.1001/jama.2013.284985

22. Luger TM, Suls J, Vander Weg MW. How robust is the association between smoking and depression in adults? A meta-analysis using linear mixed-effects models. Addict Behav. (2014) 39:1418-29. doi: 10.1016/j.addbeh.2014.05.011

23. Boden JM, Fergusson DM. Alcohol and depression. Addiction (2011) 106:906-14. doi: 10.1111/j.1360-0443.2010.03351.x

24. Quirk SE, Williams LJ, O’Neil A, Pasco JA, Jacka FN, Housden $\mathrm{S}$, et al. The association between diet quality, dietary patterns and depression in adults: a systematic review. BMC Psychiatry (2013) 13:175. doi: 10.1186/1471-244X-13-175

25. Luppino FS, de Wit LM, Bouvy PF, Stijnen T, Cuijpers P, Penninx BWJH, et al. Overweight, obesity, and depression. Arch Gen Psychiatry (2010) 67:220-9. doi: 10.1001/archgenpsychiatry.2010.2

26. Mannan M, Mamun A, Doi S, Clavarino A. Prospective associations between depression and obesity for adolescent males and females- a systematic review and meta-analysis of longitudinal studies. PLoS ONE (2016) 11:e0157240. doi: 10.1371/journal.pone.0157240

27. McEwen BS. Neurobiological and systemic effects of chronic stress. Chronic Stress (2017) 1:10.1177/2470547017692328. doi: 10.1177/2470547017692328

28. Belvederi Murri M, Pariante C, Mondelli V, Masotti M, Atti AR, Mellacqua $\mathrm{Z}$, et al. HPA axis and aging in depression: systematic 
review and meta-analysis. Psychoneuroendocrinology (2014) 41:46-62. doi: 10.1016/j.psyneuen.2013.12.004

29. Gold PW. The organization of the stress system and its dysregulation in depressive illness. Mol Psychiatry (2015) 20:32-47. doi: 10.1038/mp.2014.163

30. Stetler C, Miller GE. Depression and hypothalamic-pituitary-adrenal activation: a quantitative summary of four decades of research. Psychosom Med. (2011) 73:114-26. doi: 10.1097/PSY.0b013e31820ad12b

31. Alexopoulos GS, Morimoto SS. The inflammation hypothesis in geriatric depression. Int J Geriatr Psychiatry (2011) 26:1109-18. doi: 10.1002/gps.2672

32. Kiecolt-Glaser JK, Derry HM, Fagundes CP. Inflammation: depression fans the flames and feasts on the heat. Am J Psychiatry (2015) 172:1075-91. doi: 10.1176/appi.ajp.2015.15020152

33. Sgoifo A, Carnevali L, Pico Alfonso MDLA, Amore M. Autonomic dysfunction and heart rate variability in depression. Stress (2015) 18:343-52. doi: $10.3109 / 10253890.2015 .1045868$

34. Vancampfort D, Correll CU, Wampers M, Sienaert P, Mitchell AJ, De Herdt A, et al. Metabolic syndrome and metabolic abnormalities in patients with major depressive disorder: a meta-analysis of prevalences and moderating variables. Psychol Med. (2014) 44:2017-28. doi: 10.1017/S0033291713002778

35. Gathright EC, Goldstein CM, Josephson RA, Hughes JW. Depression increases the risk of mortality in patients with heart failure: a meta-analysis. J Psychosom Res. (2017) 94:82-9. doi: 10.1016/j.jpsychores.2017.01.010

36. Shi S, Liu T, Liang J, Hu D, Yang B. Depression and risk of sudden cardiac death and arrhythmias: a meta-analysis. Psychosom Med. (2017) 79:153-61. doi: 10.1097/PSY.00000000000 00382

37. Park M, Katon WJ, Wolf FM. Depression and risk of mortality in individuals with diabetes: a meta-analysis and systematic review. Gen Hosp Psychiatry (2013) 35:217-25. doi: 10.1016/j.genhosppsych.2013.01.006

38. Pan A, Sun Q, Oi O, Km R, Fb H. Depression and risk of stroke morbidity and mortality : a meta-analysis and systematic review. JAMA (2011) 306:2011-2. doi: 10.1001/jama.2011.1282.Depression

39. Goldstein CM, Gathright EC, Garcia S. Relationship between depression and medication adherence in cardiovascular disease: the perfect challenge for the integrated care team. Patient Prefer Adherence (2017) 11:547-59. doi: 10.2147/PPA.S127277

40. Jonkman $\mathrm{NH}$, Westland $\mathrm{H}$, Groenwold RHH, Ågren S, Atienza F, Blue L, et al. Do self-management interventions work in patients with heart failure? Circulation (2016) 133:1189-98. doi: 10.1161/CIRCULATIONAHA.115.018006

41. Mausbach BT, Schwab RB, Irwin SA. Depression as a predictor of adherence to adjuvant endocrine therapy (AET) in women with breast cancer: a systematic review and meta-analysis. Breast Cancer Res Treat. (2015) 152:239-46. doi: 10.1007/s10549-015-3471-7

42. Solmi M, Köhler CA, Stubbs B, Koyanagi A, Bortolato B, Monaco F, et al. Environmental risk factors and nonpharmacological and nonsurgical interventions for obesity: an umbrella review of meta-analyses of cohort studies and randomized controlled trials. Eur J Clin Invest. (2018) 48: 12982. doi: $10.1111 /$ eci. 12982

43. Verheggen RJHM, Maessen MFH, Green DJ, Hermus ARMM, Hopman MTE, Thijssen DHT. A systematic review and meta-analysis on the effects of exercise training versus hypocaloric diet: distinct effects on body weight and visceral adipose tissue. Obes Rev. (2016) 17:664-90. doi: 10.1111/obr.12406

44. Vancampfort D, Mitchell AJ, De Hert M, Sienaert P, Probst M, Buys R, et al. Type 2 diabetes in patients with major depressive disorder: a meta-analysis of prevalence estimates and predictors. Depress Anxiety (2015) 32:763-73. doi: $10.1002 /$ da. 22387

45. Grace A, Chan E, Giallauria F, Graham PL, Smart NA. Clinical outcomes and glycaemic responses to different aerobic exercise training intensities in type II diabetes: a systematic review and meta-analysis. Cardiovasc Diabetol. (2017) 16:37. doi: 10.1186/s12933-017-0518-6

46. Persons JE, Fiedorowicz JG. Depression and serum low-density lipoprotein: a systematic review and meta-analysis. J Affect Disord. (2016) 206:55-67. doi: 10.1016/j.jad.2016.07.033

47. Lin X, Zhang X, Guo J, Roberts CK, McKenzie S, Wu WC, et al. Effects of exercise training on cardiorespiratory fitness and biomarkers of cardiometabolic health: a systematic review and meta-analysis of randomized controlled trials. J Am Heart Assoc. (2015) 4:e002014. doi: 10.1161/JAHA.115.002014

48. Meng L, Chen D, Yang Y, Zheng Y, Hui R. Depression increases the risk of hypertension incidence: a meta-analysis of prospective cohort studies. J Hypertens. (2012) 30:842-51. doi: 10.1097/HJH.0b013e32835 080b7

49. Cornelissen VA, Smart NA. Exercise training for blood pressure: a systematic review and meta-analysis. J Am Heart Assoc. (2013) 2:e004473. doi: 10.1161/JAHA.112.004473

50. Köhler CA, Freitas TH, Maes M, de Andrade NQ, Liu CS, Fernandes BS, et al. Peripheral cytokine and chemokine alterations in depression: a meta-analysis of 82 studies. Acta Psychiatr Scand. (2017) 135:373-87. doi: $10.1111 /$ acps. 12698

51. Hayashino Y, Jackson JL, Hirata T, Fukumori N, Nakamura F, Fukuhara $S$, et al. Effects of exercise on C-reactive protein, inflammatory cytokine and adipokine in patients with type 2 diabetes: a metaanalysis of randomized controlled trials. Metabolism (2014) 63:431-40. doi: 10.1016/j.metabol.2013.08.018

52. Swardfager W, Herrmann N, Cornish S, Mazereeuw G, Marzolini S, Sham L, et al. Exercise intervention and inflammatory markers in coronary artery disease: a meta-analysis. Am Heart J. (2012) 163:666-76. doi: 10.1016/j.ahj.2011.12.017

53. Campbell JP, Turner JE. Debunking the myth of exerciseinduced immune suppression: redefining the impact of exercise on immunological health across the lifespan. Front Immunol. (2018) 9:648. doi: 10.3389/fimmu.2018.00648

54. Alvares GA, Quintana DS, Hickie IB, Guastella AJ. Autonomic nervous system dysfunction in psychiatric disorders and the impact of psychotropic medications: a systematic review and meta-analysis. J Psychiatry Neurosci. (2016) 41:89-104. doi: 10.1503/jpn.140217

55. Villafaina S, Collado-Mateo D, Fuentes JP, Merellano-Navarro E, Gusi N. Physical exercise improves heart rate variability in patients with type 2 diabetes: a systematic review. Curr Diab Rep. (2017) 17:110. doi: 10.1007/s11892-017-0941-9

56. Nolan RP, Jong P, Barry-Bianchi SM, Tanaka TH, Floras JS. Effects of drug, biobehavioral and exercise therapies on heart rate variability in coronary artery disease: a systematic review. Eur J Cardiovasc Prev Rehabil. (2008) 15:386-96. doi: 10.1097/HJR.0b013e3283030a97

57. Pearson MJ, Smart NA. Exercise therapy and autonomic function in heart failure patients: a systematic review and meta-analysis. Heart Fail Rev. (2018) 23:91-108. doi: 10.1007/s10741-017-9662-z

58. Hallgren M, Vancampfort D, Giesen ES, Lundin A, Stubbs B. Exercise as treatment for alcohol use disorders: systematic review and meta-analysis. $\mathrm{Br}$ J Sports Med. (2017) 51:1058-64. doi: 10.1136/bjsports-2016-096814

59. Hitsman B, Papandonatos GD, McChargue DE, Demott A, Herrera MJ, Spring B, et al. Past major depression and smoking cessation outcome: a systematic review and meta-analysis update. Addiction (2013) 108:294-306. doi: 10.1111/add.12009

60. Klinsophon T, Thaveeratitham P, Sitthipornvorakul E, Janwantanakul P. Effect of exercise type on smoking cessation: a meta-analysis of randomized controlled trials. BMC Res Notes (2017) 10:442. doi: 10.1186/s13104-017-2762-y

61. Grenard JL, Munjas BA, Adams JL, Suttorp M, Maglione M, McGlynn EA, et al. Depression and medication adherence in the treatment of chronic diseases in the United States: a meta-analysis. J Gen Intern Med. (2011) 26:1175-82. doi: 10.1007/s11606-011-1704-y

62. Chekroud SR, Gueorguieva R, Zheutlin AB, Paulus M, Krumholz HM, Krystal JH, et al. Association between physical exercise and mental health in 1.2 million individuals in the USA between 2011 and 2015: a cross-sectional study. Lancet Psychiatry (2018) 5:739-46. doi: 10.1016/S2215-0366(18)30227-X

63. de Vries NM, van Ravensberg CD, Hobbelen JSM, Olde Rikkert MGM, Staal JB, Nijhuis-van der Sanden MWG. Effects of physical exercise therapy on mobility, physical functioning, physical activity and quality of life in community-dwelling older adults with impaired mobility, physical disability and/or multi-morbidity: a meta-analysis. Ageing Res Rev. (2012) 11:136-49. doi: 10.1016/j.arr.2011.11.002 
64. Melanson EL. The effect of exercise on non-exercise physical activity and sedentary behavior in adults. Obes Rev. (2017) 18:40-9. doi: $10.1111 /$ obr.12507

65. Ruotsalainen H, Kyngäs H, Tammelin T, Kääriäinen M. Systematic review of physical activity and exercise interventions on body mass indices, subsequent physical activity and psychological symptoms in overweight and obese adolescents. J Adv Nurs. (2015) 71:2461-77. doi: 10.1111/jan.12696

66. Wu Q, Kling JM. Depression and the risk of myocardial infarction and coronary death. Med (2016) 95:e2815. doi: 10.1097/MD.0000000000002815

67. Anderson L, Thompson DR, Oldridge N, Zwisler A-D, Rees K, Martin N, et al. Exercise-based cardiac rehabilitation for coronary heart disease. Cochrane Database Syst. Rev. (2016) CD001800. doi: 10.1002/14651858.CD001800.pub3

68. Risom SS, Zwisler AD, Johansen PP, Sibilitz KL, Lindschou J, Gluud C, et al. Exercise-based cardiac rehabilitation for adults with atrial fibrillation. Cochrane Database Syst. Rev. (2017) 2:CD011197. doi: 10.1002/14651858.CD011197.pub2

69. Takagi H, Ando T, Umemoto T. Perioperative depression or anxiety and postoperative mortality in cardiac surgery: a systematic review and metaanalysis. Heart Vessels (2017) 32:1458-68. doi: 10.1007/s00380-017-1022-3

70. Sibilitz KL, Berg SK, Tang LH, Risom SS, Gluud C, Lindschou J, et al. Exercise-based cardiac rehabilitation for adults after heart valve surgery. Cochrane Database Syst Rev. (2013) 2013:CD010876. doi: 10.1002/14651858.CD010876

71. Miloyan B, Fried E. A reassessment of the relationship between depression and all-cause mortality in 3,604,005 participants from 293 studies. World Psychiatry (2017) 16:219-20. doi: 10.1002/wps.20439

72. Ekkekakis P, Cook DB, Craft LL, Culos-reed SN, Etnier JL, Ginis KAM. Routledge Handbook of Physical Activity and Mental Health. London: Routledge (2013).

73. Ekkekakis P, Vazou S, Bixby WR, Georgiadis E. The mysterious case of the public health guideline that is (almost) entirely ignored: call for a research agenda on the causes of the extreme avoidance of physical activity in obesity. Obes Rev. (2016) 17:313-29. doi: 10.1111/obr.12369

74. Fock KM, Khoo J. Diet and exercise in management of obesity and overweight. J Gastroenterol Hepatol. (2013) 28:59-63. doi: 10.1111/jgh.12407

75. Shaw K, Gennat H, O’Rourke P, Del Mar C. Exercise for overweight or obesity. Cochrane Database Syst Rev. (2006). doi: 10.1002/14651858.CD003817.pub3

76. Schubert MM, Sabapathy S, Leveritt M, Desbrow B. Acute exercise and hormones related to appetite regulation: a meta-analysis. Sport Med. (2014) 44:387-403. doi: 10.1007/s40279-013-0120-3

77. Marson EC, Delevatti RS, Prado AKG, Netto N, Kruel LFM. Effects of aerobic, resistance, and combined exercise training on insulin resistance markers in overweight or obese children and adolescents: a systematic review and meta-analysis. Prev Med. (2016) 93:211-8. doi: 10.1016/j.ypmed.2016.10.020

78. Umpierre D, Ribeiro PAB, Kramer CK, Leitão CB, Zucatti ATN, Azevedo MJ, et al. Physical activity advice only or structured exercise training and association with $\mathrm{HbAlc}$ levels in type 2 diabetes: a systematic review and meta-analysis. JAMA (2011) 305:1790-9. doi: 10.1001/jama.2011.576

79. Kelley GA, Kelley KS. Exercise and sleep: a systematic review of previous meta-analyses. J Evid Based Med. (2017) 10:26-36. doi: 10.1111/jebm. 12236

80. Chen C, Nakagawa S, An Y, Ito K, Kitaichi Y, Kusumi I. The exerciseglucocorticoid paradox: how exercise is beneficial to cognition, mood, and the brain while increasing glucocorticoid levels. Front Neuroendocrinol. (2017) 44:83-102. doi: 10.1016/j.yfrne.2016.12.001

81. Gerber M, Ludyga S, Mücke M, Colledge F, Brand S, Pühse U. Low vigorous physical activity is associated with increased adrenocortical reactivity to psychosocial stress in students with high stress perceptions. Psychoneuroendocrinology (2017) 80:104-13. doi: 10.1016/j.psyneuen.2017.03.004

82. Klaperski S, von Dawans B, Heinrichs M, Fuchs R. Effects of a 12-week endurance training program on the physiological response to psychosocial stress in men: a randomized controlled trial. J Behav Med. (2014) 37:1118-33. doi: 10.1007/s10865-014-9562-9
83. Besnier F, Labrunée M, Pathak A, Pavy-Le Traon A, Galès C, Sénard JM, et al. Exercise training-induced modification in autonomic nervous system: an update for cardiac patients. Ann Phys Rehabil Med. (2017) 60:27-35. doi: 10.1016/j.rehab.2016.07.002

84. Silvani A, Calandra-Buonaura G, Dampney RAL, Cortelli P. Brain-heart interactions: physiology and clinical implications. Philos Trans R Soc A Math Phys Eng Sci. (2016) 374:20150181. doi: 10.1098/rsta.2015.0181

85. Stubbs B, Rosenbaum S, Vancampfort D, Ward PB, Schuch FB. Exercise improves cardiorespiratory fitness in people with depression: a metaanalysis of randomized control trials. J Affect Disord. (2016) 190:249-53. doi: 10.1016/j.jad.2015.10.010

86. Lieberman DE. Is exercise really medicine? An evolutionary perspective. Curr Sports Med Rep. (2015) 14:313-9. doi: 10.1249/JSR.0000000000000168

87. Abrantes AM, Blevins CE, Battle CL, Read JP, Gordon AL, Stein MD. Developing a Fitbit-supported lifestyle physical activity intervention for depressed alcohol dependent women. J Subst Abuse Treat. (2017) 80:88-97. doi: 10.1016/j.jsat.2017.07.006

88. Patten CA, Bronars CA, Douglas KSV, Ussher MH, Levine JA, Tye SJ, et al. Supervised, vigorous intensity exercise intervention for depressed female smokers: a pilot study. Nicotine Tob Res. (2017) 19:77-86. doi: 10.1093/ntr/ntw208

89. Smits JAJ, Zvolensky MJ, Davis ML, Rosenfield D, Marcus BH, Church TS, et al. The efficacy of vigorous-intensity exercise as an aid to smoking cessation in adults with high anxiety sensitivity: a randomized controlled trial. Psychosom Med. (2016) 78:354-64. doi: 10.1097/PSY.0000000000000264

90. Wang D, Wang Y, Wang Y, Li R, Zhou C. Impact of physical exercise on substance use disorders: a meta-analysis. PLoS ONE (2014) 9:e110728. doi: 10.1371/journal.pone. 0110728

91. Ekkekakis P. Honey, i shrunk the pooled SMD! Guide to critical appraisal of systematic reviews and meta-analyses using the Cochrane review on exercise for depression as example. Ment Health Phys Act. (2015) 8:21-36. doi: 10.1016/j.mhpa.2014.12.001

92. Kvam S, Kleppe CL, Nordhus IH, Hovland A. Exercise as a treatment for depression: a meta-analysis. J Affect Disord. (2016) 202:67-86. doi: 10.1016/j.jad.2016.03.063

93. Krogh J, Hjorthøj C, Speyer H, Gluud C, Nordentoft M. Exercise for patients with major depression: a systematic review with metaanalysis and trial sequential analysis. BMJ Open (2017) 7:e014820. doi: 10.1136/bmjopen-2016-014820

94. Stubbs B, Vancampfort D, Rosenbaum S, Ward PB, Richards J, Soundy A, et al. Dropout from exercise randomized controlled trials among people with depression: a meta-analysis and meta regression. J Affect Disord. (2016) 190:457-66. doi: 10.1016/j.jad.2015.10.019

95. Schuch FB, Dunn AL, Kanitz AC, Delevatti RS, Fleck MP. Moderators of response in exercise treatment for depression: a systematic review. J Affect Disord. (2016) 195:40-9. doi: 10.1016/j.jad.2016.01.014

96. Stubbs B, Vancampfort D, Rosenbaum S, Ward PB, Richards J, Ussher M, et al. Challenges establishing the efficacy of exercise as an antidepressant treatment: a systematic review and meta-analysis of control group responses in exercise randomised controlled trials. Sport Med. (2016) 46:699-713. doi: 10.1007/s40279-015-0441-5

97. Sukhato K, Lotrakul M, Dellow A, Ittasakul P, Thakkinstian A, Anothaisintawee T. Efficacy of home-based non-pharmacological interventions for treating depression: a systematic review and network meta-analysis of randomised controlled trials. BMJ Open (2017) 7:e014499. doi: 10.1136/bmjopen-2016-014499

98. Cipriani A, Furukawa TA, Salanti G, Chaimani A, Atkinson LZ, Ogawa Y, et al. Comparative efficacy and acceptability of 21 antidepressant drugs for the acute treatment of adults with major depressive disorder: a systematic review and network meta-analysis. Lancet (2018) 391:1357-66. doi: 10.1016/S0140-6736(17)32802-7

99. Lindheimer JB, O'Connor PJ, Dishman RK. Quantifying the placebo effect in psychological outcomes of exercise training: a meta-analysis of randomized trials. Sport Med. (2015) 45:693-711. doi: 10.1007/s40279-015-0303-1

100. Szabo A. Acute psychological benefits of exercise: reconsideration of the placebo effect. J Ment Heal. (2013) 22:449-55. doi: $10.3109 / 09638237.2012 .734657$ 
101. Ravindran AV, Balneaves LG, Faulkner G, Ortiz A, McIntosh D, Morehouse RL et al. Canadian network for mood and anxiety treatments (CANMAT) 2016 clinical guidelines for the management of adults with major depressive disorder. Can J Psychiatry. (2016) 61:576-87. doi: 10.1177/0706743716660290

102. Nebiker L, Lichtenstein E, Minghetti A, Zahner L, Gerber M, Faude $\mathrm{O}$, et al. Moderating effects of exercise duration and intensity in neuromuscular vs. Endurance exercise interventions for the treatment of depression: a meta-analytical review. Front Psychiatry (2018) 9:305. doi: 10.3389/fpsyt.2018.00305

103. Paolucci EM, Loukov D, Bowdish DME, Heisz JJ. Exercise reduces depression and inflammation but intensity matters. Biol Psychol. (2018) 133:79-84. doi: 10.1016/j.biopsycho.2018.01.015

104. Ekkekakis P, Parfitt G, Petruzzello SJ. The pleasure and displeasure people feel when they exercise at different intensities: decennial update and progress towards a tripartite rationale for exercise intensity prescription. Sport Med. (2011) 41:641-71. doi: 10.2165/11590680-000000000-00000

105. Toups M, Carmody T, Greer T, Rethorst C, Grannemann B, Trivedi $\mathrm{MH}$. Exercise is an effective treatment for positive valence symptoms in major depression. J Affect. (2017) 209:188-94. doi: 10.1016/j.jad.2016. 08.058

106. Vancampfort D, Hallgren M, Firth J, Rosenbaum S, Schuch FB, Mugisha J, et al. Physical activity and suicidal ideation: a systematic review and metaanalysis. J Affect Disord. (2018) 225:438-48. doi: 10.1016/j.jad.2017.08.070

107. Ahern E, Semkovska M. Cognitive functioning in the first-episode of major depressive disorder: a systematic review and meta-analysis. Neuropsychology (2017) 31:52-72. doi: 10.1037/neu0000319

108. Brondino N, Rocchetti M, Fusar-Poli L, Codrons E, Correale L, Vandoni M, et al. A systematic review of cognitive effects of exercise in depression. Acta Psychiatr Scand. (2017) 135:285-95. doi: 10.1111/acps. 12690

109. Greer TL, Furman JL, Trivedi MH. Evaluation of the benefits of exercise on cognition in major depressive disorder. Gen Hosp Psychiatry (2017) 49:19-25. doi: 10.1016/j.genhosppsych.2017.06.002

110. Sun M, Lanctot K, Herrmann N, Gallagher D. Exercise for cognitive symptoms in depression: a systematic review of interventional studies. Can J Psychiatry (2017) 63:115-28. doi: 10.1177/0706743717738493

111. Schuch FB, Deslandes AC, Stubbs B, Gosmann NP, Silva CTBda, Fleck MPde A. Neurobiological effects of exercise on major depressive disorder: a systematic review. Neurosci Biobehav Rev. (2016) 61:1-11. doi: 10.1016/j.neubiorev.2015.11.012

112. Legrand FD, Neff EM. Efficacy of exercise as an adjunct treatment for clinically depressed inpatients during the initial stages of antidepressant pharmacotherapy: an open randomized controlled trial. J Affect Disord. (2016) 191:139-44. doi: 10.1016/j.jad.2015.11.047

113. Minghetti A, Faude O, Hanssen H, Zahner L, Gerber M, Donath L. Sprint interval training (SIT) substantially reduces depressive symptoms in major depressive disorder (MDD): a randomized controlled trial. Psychiatry Res. (2018) 265:292-7. doi: 10.1016/j.psychres.2018. 04.053

114. Schuch FB, Vasconcelos-Moreno MP, Borowsky C, Zimmermann AB, Rocha NS, Fleck MP. Exercise and severe major depression: effect on symptom severity and quality of life at discharge in an inpatient cohort. J Psychiatr Res. (2015) 61:25-32. doi: 10.1016/j.jpsychires.2014.11.005

115. Greer TL, Trombello JM, Rethorst CD, Carmody TJ, Jha MK, Liao A, et al. Improvements in psychosocial functioning and health-related quality of life following exercise augmentation in patients with treatment response but nonremitted major depressive disorder: results from the tread study. Depress Anxiety (2016) 33:870-81. doi: 10.1002/da.22521

116. Mura G, Moro MF, Patten SB, Carta MG. Exercise as an add-on strategy for the treatment of major depressive disorder: a systematic review. CNS Spectr. (2013) 19:496-508. doi: 10.1017/S1092852913000953

117. Poyatos-León R, García-Hermoso A, Sanabria-Martínez G, Álvarez-Bueno C, Cavero-Redondo I, Martínez-Vizcaíno V. Effects of exercise-based interventions on postpartum depression: a meta-analysis of randomized controlled trials. Birth (2017) 44:200-8. doi: 10.1111/birt.12294

118. Carter T, Morres ID, Meade O, Callaghan P. The effect of exercise on depressive symptoms in adolescents: a systematic review and meta-analysis. J Am Acad Child Adolesc Psychiatry (2016) 55:580-90. doi: 10.1016/j.jaac.2016.04.016

119. Radovic S, Gordon MS, Melvin GA. Should we recommend exercise to adolescents with depressive symptoms? A meta-analysis. J Paediatr Child Health (2017) 53:214-20. doi: 10.1111/jpc.13426

120. Mammen G, Faulkner G. Physical activity and the prevention of depression: a systematic review of prospective studies. Am J Prev Med. (2013) 45:649-57. doi: 10.1016/j.amepre.2013.08.001

121. Schuch FB, Vancampfort D, Firth J, Rosenbaum S, Ward PB, Silva ES, et al. Physical activity and incident depression: a meta-analysis of prospective cohort studies. Am J Psychiatry (2018) 175:631-48. doi: 10.1176/appi.ajp.2018.17111194

122. Haigh EAP, Bogucki OE, Sigmon ST, Blazer DG. Depression among older adults: a 20-year update on five common myths and misconceptions. Am J Geriatr Psychiatry (2017) 26:107-22. doi: 10.1016/j.jagp.2017.06.011

123. Hegeman AJM, Kok RM, Van Der Mast RC, Giltay EJ. Phenomenology of depression in older compared with younger adults: meta-analysis. $\mathrm{Br} \mathrm{J}$ Psychiatry (2012) 200:275-81. doi: 10.1192/bjp.bp.111.095950

124. Naismith SL, Norrie LM, Mowszowski L, Hickie IB. The neurobiology of depression in later-life: clinical, neuropsychological, neuroimaging, and pathophysiological features. Prog Neurobiol. (2012) 98:99-143. doi: 10.1016/j.pneurobio.2012.05.009

125. Alexopoulos GS. Depression in the elderly. Lancet (2005) 365:1961-70. doi: 10.1016/S0140-6736(05)66665-2

126. Morimoto SS, Alexopoulos GS. Cognitive deficits in geriatric depression. Clinical correlates and implications for current and future treatment. Psychiatr Clin North Am. (2013) 36:517-31. doi: 10.1016/j.psc.2013.08.002

127. Taylor WD, Aizenstein HJ, Alexopoulos GS. The vascular depression hypothesis: mechanisms linking vascular disease with depression. $\mathrm{Mol}$ Psychiatry (2013) 18:963-74. doi: 10.1038/mp.2013.20

128. Tedeschini E, Levkovitz Y, Iovieno N, Ameral VE, Nelson JC, Papakostas GI. Efficacy of antidepressants for late-life depression: a meta-analysis and metaregression of placebo-controlled randomized trials. J Clin Psychiatry (2011) 72:1660-8. doi: 10.4088/JCP.10r06531

129. Bridle C, Spanjers K, Patel S, Atherton NM, Lamb SE. Effect of exercise on depression severity in older people: systematic review and metaanalysis of randomised controlled trials. Br J Psychiatry (2012) 201:180-5. doi: 10.1192/bjp.bp.111.095174

130. Catalan-Matamoros D, Gomez-Conesa A, Stubbs B, Vancampfort D. Exercise improves depressive symptoms in older adults: an umbrella review of systematic reviews and meta-analyses. Psychiatry Res. (2016) 244:202-9. doi: $10.1016 /$ j.psychres.2016.07.028

131. Schuch FB, Vancampfort D, Rosenbaum S, Richards J, Ward PB, Veronese N, et al. Exercise for depression in older adults: a meta-analysis of randomized controlled trials adjusting for publication bias. Rev Bras Psiquiatr. (2016) 38:247-54. doi: 10.1590/1516-4446-2016-1915

132. Belvederi Murri M, Amore M, Menchetti M, Toni G, Neviani F, Cerri M, et al. Physical exercise for late-life major depression. Br J Psychiatry (2015) 207:235-42. doi: 10.1192/bjp.bp.114.150516

133. Murri MB, Ekkekakis P, Menchetti M, Neviani F, Trevisani F, Tedeschi S, et al. Physical exercise for late-life depression: effects on symptom dimensions and time course. J Affect Disord. (2018) 230:65-70. doi: 10.1016/j.jad.2018.01.004

134. Neviani F, Murri MB, Mussi C, Triolo F, Toni G, Simoncini E, et al. Physical exercise for late life depression: effects on cognition and disability. Int Psychogeriatrics (2017) 29:1105-12. doi: 10.1017/S1041610217000576

135. Toni G, Belvederi Murri M, Piepoli M, Zanetidou S, Cabassi A, Squatrito S, et al. Physical exercise for late-life depression: effects on heart rate variability. Am J Geriatr Psychiatry (2016) 24:989-97. doi: 10.1016/j.jagp.2016.08.005

136. Zanetidou S, Belvederi Murri M, Menchetti M, Toni G, Asioli F, Bagnoli L, et al. Physical exercise for late-life depression: customizing an intervention for primary care. J Am Geriatr Soc. (2017) 65:348-55. doi: 10.1111/jgs.14525

137. Kelly ME, Loughrey D, Lawlor BA, Robertson IH, Walsh C, Brennan S. The impact of exercise on the cognitive functioning of healthy older adults: a systematic review and meta-analysis. Ageing Res Rev. (2014) 16:12-31. doi: 10.1016/j.arr.2014.05.002

138. Cai H, Li G, Hua S, Liu Y, Chen L. Effect of exercise on cognitive function in chronic disease patients: a meta-analysis and systematic review 
of randomized controlled trials. Clin Interv Aging (2017) 12:773-83. doi: $10.2147 /$ CIA.S135700

139. Groot C, Hooghiemstra AM, Raijmakers PGHM, van Berckel BNM, Scheltens P, Scherder EJA, et al. The effect of physical activity on cognitive function in patients with dementia: a meta-analysis of randomized control trials. Ageing Res Rev. (2016) 25:13-23. doi: 10.1016/j.arr.2015.11.005

140. Panza GA, Taylor BA, MacDonald HV, Johnson BT, Zaleski AL, Livingston J, et al. Can exercise improve cognitive symptoms of Alzheimer's disease? J Am Geriatr Soc. (2018) 66:487-95. doi: 10.1111/jgs.15241

141. Zheng G, Xia R, Zhou W, Tao J, Chen L. Aerobic exercise ameliorates cognitive function in older adults with mild cognitive impairment: a systematic review and meta-analysis of randomised controlled trials. Br J Sports Med. (2016) 50:1443-50. doi: 10.1136/bjsports-2015095699

142. Rosenbaum S, Hobson-Powell A, Davison K, Stanton R, Craft LL, Duncan $\mathrm{M}$, et al. The role of sport, exercise, and physical activity in closing the life expectancy gap for people with mental illness: an international consensus statement by exercise and sports science australia, american college of sports medicine, british association o. Transl J Am Coll Sport Med. (2018) 3:72-3. doi: 10.1249/TJX.0000000000000061

143. Searle A, Calnan M, Turner KM, Lawlor DA, Campbell J, Chalder M, et al. General Practitioners' beliefs about physical activity for managing depression in primary care. Ment Health Phys Act. (2012) 5:13-9. doi: 10.1016/j.mhpa.2011.11.001

144. Stanton R, Franck C, Reaburn P, Happell B. A pilot study of the views of general practitioners regarding exercise for the treatment of depression. Perspect Psychiatr Care (2014) 51:253-9. doi: 10.1111/ppc.12088

145. Kok RM, Reynolds CF III. Management of depression in older adults: a review. JAMA (2017) 317:2114-22. doi: 10.1001/jama.2017.5706

146. Ekkekakis P, Murri MB. Exercise as antidepressant treatment: time for the transition from trials to clinic? Gen Hosp Psychiatry (2017) 49:1-5. doi: 10.1016/j.genhosppsych.2017.11.004

147. Netz Y. Is the Comparison between exercise and pharmacologic treatment of depression in the clinical practice guideline of the American college of physicians evidence-based? Front Pharmacol. (2017) 8:257. doi: 10.3389/fphar.2017.00257

148. Baron DA, Lasarow S, Baron SH. Exercise for the treatment of depression. In: Lam LCW, Riba M, editors. Physical Exercise Interventions for Mental Health. Cambridge: Cambridge University Press (2016). p. 26-40. doi: 10.1017/СBO9781316157565.004

149. Nyström MBT, Neely G, Hassmén P, Carlbring P. Treating major depression with physical activity: a systematic overview with recommendations. Cogn Behav Ther. (2015) 44:341-52. doi: 10.1080/16506073.2015.10 15440

150. Rethorst CD, Trivedi MH. Evidence-based recommendations for the prescription of exercise for major depressive disorder. J Psychiatr Pract. (2013) 19:204-12. doi: 10.1097/01.pra.0000430504.16952.3e

151. Stanton R, Happell BM. An exercise prescription primer for people with depression. Issues Ment Health Nurs. (2013) 34:626-30. doi: $10.3109 / 01612840.2012 .758207$
152. Stanton R, Reaburn P. Exercise and the treatment of depression: a review of the exercise program variables. J Sci Med Sport (2014) 17:177-82. doi: 10.1016/j.jsams.2013.03.010

153. Garber CE, Blissmer B, Deschenes MR, Franklin BA, Lamonte MJ, Lee IM, et al. Quantity and quality of exercise for developing and maintaining cardiorespiratory, musculoskeletal, and neuromotor fitness in apparently healthy adults: guidance for prescribing exercise. Med Sci Sports Exerc. (2011) 43:1334-59. doi: 10.1249/MSS.0b013e318213fefb

154. Ladwig MA, Hartman ME, Ekkekakis P. Affect-based Exercise Prescription: an Idea Whose Time Has Come? ACSMs Health Fit J. (2017) 21:10-5. doi: 10.1249/FIT.0000000000000332

155. Mata J, Hogan CL, Joormann J, Waugh CE, Gotlib IH. Acute exercise attenuates negative affect following repeated sad mood inductions in persons who have recovered from depression. J Abnorm Psychol. (2013) 122:45-50. doi: 10.1037/a0029881

156. Mata J, Thompson RJ, Jaeggi SM, Buschkuehl M, Jonides J, Gotlib IH. Walk on the bright side: physical activity and affect in major depressive disorder. $J$ Abnorm Psychol. (2012) 121:297-308. doi: 10.1037/a0023533

157. Weinstein AA, Deuster PA, Francis JL, Beadling C, Kop WJ. The role of depression in short-term mood and fatigue responses to acute exercise. Int J Behav Med. (2010) 17:51-7. doi: 10.1007/s12529-009-9046-4

158. Rhodes RE, Kates A. Can the affective response to exercise predict future motives and physical activity behavior? A systematic review of published evidence. Ann Behav Med. (2015) 49:715-31. doi: 10.1007/s12160-015-9704-5

159. Williams DM, Dunsiger S, Miranda R, Gwaltney CJ, Emerson JA, Monti PM, et al. Recommending self-paced exercise among overweight and obese adults: a randomized pilot study. Ann Behav Med. (2015) 49:280-5. doi: 10.1007/s12160-014-9642-7

160. Rethorst CD, South CC, Rush AJ, Greer TL, Trivedi MH. Prediction of treatment outcomes to exercise in patients with nonremitted major depressive disorder. Depress Anxiety (2017) 34:1116-22. doi: 10.1002/da.22670

161. Suterwala AM, Rethorst CD, Carmody TJ, Greer TL, Grannemann BD, Jha $\mathrm{M}$, et al. Affect following first exercise session as a predictor of treatment response in depression. J Clin Psychiatry (2016) 77:1036-42. doi: 10.4088/JCP. $15 \mathrm{~m} 10104$

Conflict of Interest Statement: The authors declare that the research was conducted in the absence of any commercial or financial relationships that could be construed as a potential conflict of interest.

Copyright (๑) 2019 Belvederi Murri, Ekkekakis, Magagnoli, Zampogna, Cattedra, Capobianco, Serafini, Calcagno, Zanetidou and Amore. This is an open-access article distributed under the terms of the Creative Commons Attribution License (CC BY). The use, distribution or reproduction in other forums is permitted, provided the original author(s) and the copyright owner(s) are credited and that the original publication in this journal is cited, in accordance with accepted academic practice. No use, distribution or reproduction is permitted which does not comply with these terms. 